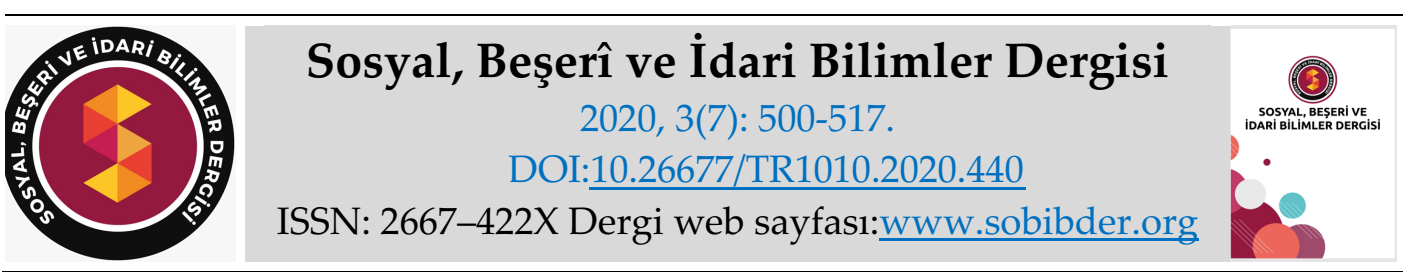

ARAȘTIRMA MAKALESİ

\title{
Kamuyu Bilgilendirme Modeli Çerçevesinde Covid 19 Süreci; Dr. Fahrettin Koca Instagram Hesabı Analizi
}

Dr. Öğr. Üyesi Hicran Özlem ILGIN, Çanakkale Onsekiz Mart Üniversitesi, Ezine MYO, Çanakkale, e-posta: hicranilgin@comu.edu.tr ORCID: https://orcid.org/0000-0002-0549-0710

Öğr. Gör Şaziye Ceren ULUPINAR, Çanakkale Onsekiz Mart Üniversitesi, Ezine MYO, Çanakkale, e-posta: cerenuzunay@comu.edu.tr ORCID: https://orcid.org/0000-0002-2895-5437

Öz Kurumlar sosyal medya uygulamalarını stratejik planları içinde değerlendirirken kamuyu bilgilendirme süreçleri içinde de kullanmaya da başlamıştır. 2019 yılının sonu itibariyle Çin'de ortaya çıkarak tüm dünyayı etkisi altına alan Covid-19 salgını diğer dünya ülkelerinde olduğu gibi Türkiye'yi de etkisi altına almıştır. Bu süreçte Türkiye'de de resmi kurumlar nezdinde önlemler alınmış ve hastalığın yayılımını önlemek üzere uygulamalar geliştirilmiştir. $\mathrm{Bu}$ uygulamaların kamuya aktarılması ve Sağlık Bakanlığı'nın faaliyetlerine ilişkin olarak Sağlık Bakanı Dr. Fahrettin Koca'nın resmi Instagram hesabından gerçekleştirilen paylaşımlar bu araştırmanın konusunu oluşturmaktadır. Hastalığın birinci dönemi olarak ifade eden süreç dâhilinde 01 Mart 2020-30 Nisan 2020 tarihleri arasında Dr. Fahrettin Koca'nın resmi Instagram hesabı Kamuyu bilgilendirme modeli çerçevesinde içerik analizi yöntemi ile değerlendirilmiş ve 286 gönderi kayıt altına alınmıştır. Bu noktada çalışma sonucunda gönderilerin özellikle kamuyu bilgilendirme gönderileri kategorisinde özellikle basın toplantısı kesitleri ve günlük vaka rakamları noktasında paylaşımlar için değerlendirildiği belirlenmiştir. Bunun yanı sıra kamunun bu hesaptan paylaşılan gönderilere yüksek oranda etkileşim gösterdiğidir.

Anahtar Kelimeler: Halkla İlişkiler, Kamuyu Bilgilendirme Modeli, Instagram, Covid-19, Dr. Fahrettin Koca.

Makale Gönderme Tarihi: 01.05.2020

Makale Kabul Tarihi: 03.07.2020

\section{Önerilen Atıf:}

Ilgın, H. Ö. ve Ulupınar, Ş. C. (2020). Kamuyu Bilgilendirme Modeli Çerçevesinde Covid 19 Süreci; Dr. Fahrettin Koca Instagram Hesabı Analizi, Sosyal, Beşeri ve İdari Bilimler Dergisi, 3(7): 500-517.

(c) 2020 Sosyal, Beşerî ve İdari Bilimler Dergisi. 


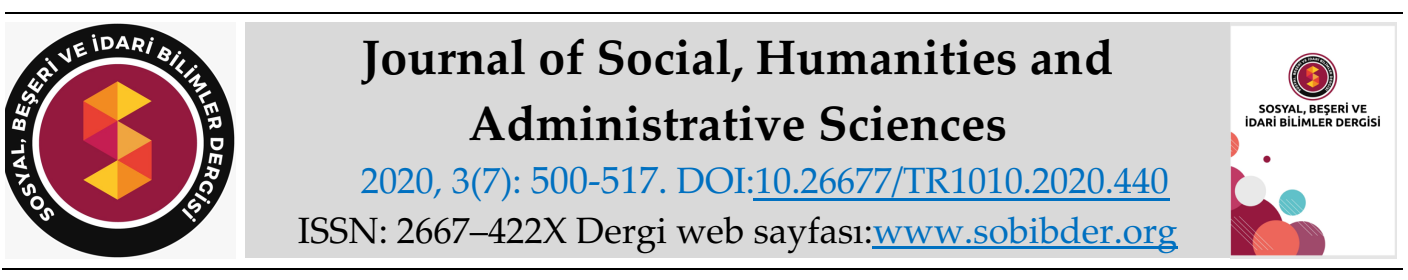

RESEARCH PAPER

\title{
Covid 19 Process in The Framework of Public Information Model; Dr. Fahrettin Koca Instagram Account Analysis
}

Assistant Prof. Dr. Hicran Özlem ILGIN, Çanakkale Onsekiz Mart University, Ezine Vocational School, Çanakkale, e-mail: hicranilgin@comu.edu.tr ORCID: https://orcid.org/0000-0002-0549-0710

Lecturer Şaziye Ceren ULUPINAR, Çanakkale Onsekiz Mart University, Ezine Vocational School, Çanakkale, e-mail: cerenuzunay@comu.edu.tr ORCID: https://orcid.org/0000-0002-2895-5437

\begin{abstract}
While institutions evaluate social media applications within their strategic plans, they have also started to use them in public information processes. At the end of the 2019 Covid19 influenced China and the Other countries in the world like Turkey. In this process, official organizations in Turkey also taken measures and practices have been developed to prevent the spread of the disease. Regarding the transfer of these applications to the public and Sharing from the activities of the Ministry of Health, the Minister of Health Dr. Fahrettin Koca's official Instagram account is the subject of this research. Within the process, which is the first period of the disease, between 01 March 2020 and 30 April 2020. The official Instagram account of Fahrettin Koca was evaluated by the content analysis method within the framework of the Public Information Model and 286 posts were recorded. At this point, as a result of the study, it was determined that the posts were evaluated especially for sharing in the category of public information posts, especially in terms of press conference sections and daily case figures. In addition, the public is highly engaged with posts shared from this account.
\end{abstract}

Keywords: Public Relations, Public Information Model, Instagram, Covid-19 Dr. Fahrettin Koca. Received: 01.05.2020

Accepted: 03.07.2020

\footnotetext{
Suggested Citation:

Ilgın, H. Ö. and Ulupınar, Ş. C. (2020). Covid 19 Process in The Framework of Public Information Model; Dr. Fahrettin Koca Instagram Account Analysis, Journal of Social, Humanities and Administrative Sciences, 3(7): 500-517.

(c) 2020 Sosyal, Beşerî ve İdari Bilimler Dergisi.
} 


\section{Gíriş}

Kamuyu bilgilendirme modeli halkla ilişkilerde, siyasi bakımdan en sık kullanılan yöntemlerin başında gelmektedir. Kamuyu bilgilendirmede asıl amaç, yürütülen faaliyetlerin insanlara ve topluma duyurulması aynı zamanda olumlu tutumların artmasını sağlamaktır. Bu model ile ikinci basamak halkla ilişkiler modeli 1900'lerin başlarında kamuyu bilgilendirme çerçevesinde basın ile iletişim kurarak başlamıştır. Bugün ise dönüşen yeni dünya düzeni içerisinde yeni medya ve yeni uygulama alanları kurumlar tarafından kullanılır hale gelmiştir. Kurumların halkla ilişkiler amaçlı sosyal medya adı altında kullanımı başlarda web sayfalarını kullanarak gerçekleştirdiği bilinmektedir. Bu süreçten hareketle kurumlar her türlü ürün ve hizmetlerini duyurabilmek amaçlı web sayfalarını hazırlayıp internet ortamına sunarak sanal ortama giriş yapmışlardır. Kamuyu bilgilendirme amacı taşıdıkları haber bültenlerini hem kendi web sayfalarında yayınlamışlar hem de e-haber olarak hazırlayıp kullanıcılarının e-mail adreslerine göndermişlerdir. Daha sonra web 2.0 teknolojisinin gelişmesiyle birlikte internet ortamında kullanıcısı sayısı artmış ve yaşanan bu artış bilgi akışı konusunda önemli bir güç kaynağı oluşturmuştur. Bu noktada farkındalık edinen kurumlar içerik üretmeye ve üretilen içeriği kullanıcılarıyla paylaşmaya başlamış ve her geçen gün yeni uygulamaları dener hale gelmişlerdir. Google'ı keşfeden kurumlar bloglar ve sosyal ağ ortamlarını oluşturmaya başlamışlar ve bu yöntemlerle kullanıcılarına ulaşmak için zaman ve mekân kaygısı gütmeden bünyesinde milyonlarca kullanıcıyı barındıran sosyal medyanın araçlarından faydalanır hale gelmişlerdir. Bu bağlamda sosyal medya zaman ve mekân sınırlaması olmadan etkileşimin güçlü olduğu aynı zamanda yönetsel ve siyasal hayatta da etkili bir şekilde kullanılan önemli bir iletişim aracı haline gelmiştir. Siyasiler ve yöneticiler de kurum ve kuruluşlar gibi etkili bir şekilde kullanılan sosyal medya araçlarını kullanmaya başlamıştır. Günümüzde kişilerin ve toplumun hızla değiştiği bu süreçte kurumların sosyal medya araçlarından bağımsız olduğu düşünülemez hale gelmiştir.

Bu çalışma ana eksenini küresel salgın Covid-19'dan almaktadır. Bugün bu çalışmanın yapıldığı tarihlerde henüz dünyanın "savaşttğı" bir virüs olarak önemini koruyan yeni tip koronovirüs hastalığı (COVID-19) Çin'in Wuhan kentinde hastalarda nefes darlığı ve ölümle sonuçlanan vakalarla ortaya çıkmış ve Ocak 2020 'de ilk olarak tanımlanmıştır. Hastalık öncelikle deniz ürünleri ve hayvan pazarında çalışanlarda tespit edilmiş buradan tüm Çin'e ve dünyaya yayılmıştır. Koronavirusler (CoV), soğuk algınlığından Orta Doğu Solunum Sendromu (MERS$\mathrm{CoV}$ ) ve Şiddetli Akut Solunum Sendromu (SARS-CoV) gibi daha ciddi hastalıklara kadar çeşitli hastalıklara neden olan büyük bir virüs ailesidir (https://covid19bilgi.saglik.gov.tr/tr/).

Türkiye'de ise ilk vaka tespiti 11 Mart 2020'de gerçekleşmiş ve dünyada olduğu gibi hızla önlemler alınmaya başlanmıştır. Bu çerçevede Türkiye'de ilk önce Milli Eğitim Bakanlığı'na bağlı okullar 13 Mart 2020 itibariyle tatil edilerek kısa sürede uzaktan eğitime geçilmiş YÖK de aynı kararları üniversiteler nezdinden almıştır. Hastalığın Türkiye'de ilk vaka tespiti yurt dışı kaynaklı hastalık taşıyıcısı ile temastan kaynaklandığı tespit edilmiştir ve bu süreçte yurt dışından gelenlerin karantinaya alınma süreçleri ve özel/kamu sektöründe çalışanlara esnek ve uzaktan çalışma düzeni getirilmiştir. Hastalığa ilişkin gelişmeler yaşandıkça buna bağlı olarak büyükşehirlere giriş çıkış sınırlandırmaları, hafta sonları sokağa çıkma kısıtlamaları ve buna benzer önlemler alınmıştır (https://www.icisleri.gov.tr/).

$\mathrm{Bu}$ çerçevede resmi kaynakların yaptıkları bilgilendirmeler için kullanılan sosyal medya uygulamaları, kullanıcılar için özellikle resmi kaynak niteliğindeki hesaplar bağlamında güvenilir ve hızlı bir bilgi kaynağı olarak dünyada olduğu gibi ülkemizde de kullanılmıştır. Bu çalışma dönemin Sağlık Bakanı Dr. Fahrettin Koca'nın resmi Instagram hesabı üzerinden yaptığı paylaşımları kamuyu bilgilendirme modeli çerçevesinde değerlendirerek, kamunun etkileşimini 
de analiz etmeyi amaçlamıştır. Bu doğrultuda 01 Mart 2020-30 Nisan 2020 tarihileri arasında Dr. Fahrettin Koca'nın resmi Instagram hesabı içerik analizi yöntemi ile analiz edilerek bulguları değerlendirilmiştir.

\section{KAMUYU BİLGİLENDİRME MODELİ}

Halkla ilişkilerin tarihçesini esas alarak Grunig ve Hunt'ın (1984:12-13) geliştirdiği halkla ilişkiler modelleri dört basamakta ifade edilmektedir. Buna göre birinci basamakta basın ajansı modelinin ardından özellikle kamunun kişi ya da kuruma ilişkin bilgilenmesi amacını taşıyan kamuyu bilgilendirme modeli ikinci basamak halkla ilişkiler modeli olarak bilinmektedir. Bu model bir kişi veya kuruluşun kendisi ve gerçekleştirdiği faaliyetlere ilişkin hedef kitlesine bilgi vermesi biçiminde tanımlanabilir (Okay ve Okay, 2002: 124). Kısaca modelde temel amaç kuruma ya da kişiye ilişkin kamuya bilgi aktarımı sağlamaktır.

Kamuyu bilgilendirme modelinin ilk uygulayıcısı olarak bilinen Ivy Lee, bir şirkette 1916 yılında danışman olarak çalışma hayatına başlayan ve iş hayatında yaşam şartlarında hüküm süren gizlilik politikasını yıkan bir gazeteci olarak bilinmekle beraber, halkla ilişkiler mesleğinin de önemli ismi olarak tanınmaktadır. Ivy Lee'nin uygulayıcısı olduğu modele göre, kamuyu bilgilendirme politikasında halkla ilişkilerin önemli rolü, kurum ve kuruluşlar bakımından gerekli bilgileri, ilgili kurum ve kişilerle paylaşan gazeteci rolüne benzetilebilir (Grunig ve Hunt, 1984: 33). Bu model kişi ve organizasyon hakkında doğru ve dürüst bilgi aktarılmasını esas almaktadır (Harrison, 2004: 46, Erdoğan, 2006:187). Kamuyu bilgilendirme modelinde bilgi paylaşımı kurumun öngörüleri çerçevesinde gelişmektedir, bu nedenle kamuyu bilgilendirme modelini asimetrik olarak değerlendirmek mümkündür. Model ikna etme amacı gütmez, amaç sadece bilgilerin objektif bir biçimde kamuya aktarılmasıdır. Kurumlar modeli uygularken dergiler, broşürler, filmler, bilgi notları gibi iletişim araçlarını kamuyu bilgilendirmek amacına sunarak halkla ilişkiler programlarını gerçekleştirirler (Grunig, 1990: 24-25). Günümüzde daha çok devlet, ticari organizasyonlar, sivil tolum kuruluşları tarafından kullanılmaktadır (Erdoğan, 2006:187). Bugün ülkemizde de bakanlıklar ve diğer devlet kurumları tarafından kamuyu bilgilendirme modeli kullanıldığı bilinmektedir.

Kamuyu bilgilendirme modelinde kurum kamuyu manipülatif taktikler uygulanmaz (https://ohiostate.pressbooks.pub/stratcommwriting/chapter/four-models-of-public-relations/).

Kamuyu bilgilendirme modeli genel anlamda kurumların, kamuoyu ile paylaştıkları bilgiler dâhilinde tanınmışlık düzeyine de katkı sağlanmaktadır. Herhangi bir kurum ya da kuruluşun kamuoyunu göz ardı etmesi mümkün değildir. Bu bağlamda kamuyu bilgilendirme faaliyetleri ile kurumlara ve yürütülen faaliyetlere karşı güven ortamı ve olumlu bir imaj yaratılır. Kamunun olaylardan haberdar edilebilmesi için basınla ilişkilerin istikrarlı ve sağlıklı olarak yürütülmesi gerekmektedir (Ertekin, 2000:12). Kamu kuruma ilişkin bilgileri şeffaf bir biçimde elde ettikçe kurumun imajı kamu nezdinde olumlu bir biçimde yapılanmaktadır. Bu nedenledir ki kurumlar basın, yayın organları yoluyla bilgilendirmeler yapmayı ve bunu sistematik hale getirmeyi bir halkla ilişkiler stratejisi olarak benimsemektedir.

\section{KAMUYU BİLGİLENDİRME ARACI OLARAK SOSYAL MEDYA}

Halkla ilişkiler disiplininin geleneksel medya uygulamaları dışında, internetin hayatımızda büyük bir yere sahip olması ve web 2.0 uygulamalarının iletişim kanalında ilgi görmesiyle birlikte artık sosyal ağ araçlarının da gerekli olduğu anlaşılmış ve bu alana önem verilmeye başlanmıştır (Özgen, 2012: 11). Halkla ilişkilerde hedef kitle ile kurumların arasında önemli rol oynayan geleneksel medyaya karşı iletişim için önemli bir kanal haline gelen sosyal medyanın yükselişi görülmektedir. Sosyal medya sayesinde kurumlar ortaya bir kriz durumu çıktı̆̆ında doğru zamanda müdahale edip krizi yönetebilir. Bu bağlamda sosyal medyanın içerdiği 
paylaşımlarla oluşan kitle, halkla ilişkiler uzmanları gözüyle sorunları ve endişeleri de gündeme getirmektedir. Ancak sosyal medyanın bu yapısı ihmal edilmiş ya da ulaşılamayan kitlelere ulaşmada halkla ilişkiler uzmanlarına büyük olanaklar sağlamaktadır (Khang vd., 2012: 281).

Kamu kurum ve kuruluşları günümüzde geleneksel medya araçlarının kullanımı yanı sıra yeni medya araçlarını, bilgilendirme, tanıtma, haber verme, kriz yönetimi, kurum imajı gibi halkla ilişkiler faaliyetleri için kullanmaya başlamışlardır (Kazaz ve Tümen, 2013: 89). Konuk ve Özçelik' in de belirttiği üzere "Kamu kurumları değişimin bir parçası olmakla birlikte yeni medya uygulamalarını oluşturmak, bu uygulamaları güçlü kılmak ve nihayetinde beklenen hizmeti gerçekleştirmek için sürekli olarak kendilerini geliştirmek durumundadır. Kamu kurumlarının işleyişinden kaynaklanan bazı kısıtlar olsa dahi sosyal medya araçları (Facebook, Twitter, Instagram vb.), verilen hizmetlerin duyurulması, vatandaş ilişkilerinin daha yakın olması, beklentilerin bilinmesi ve göz önüne alınması bakımından etkili iletişim kanallarıdır" Özçelik ve Konuk, 2020: 47).

Kamuyu bilgilendirme modeli kuruluşlardan hedef kitlelerine tek yönlü olarak işler (Peltekoğlu, 2009: 128). Sosyal medya platformları halkın genel anlamda ihtiyaçlarını öğrenmek, yapılan projeler hakkındaki tavrını değerlendirmek için yöneticilere fırsat sunmaktadır. İhtiyaçların doğru belirlenmesiyle kaynakların daha verimli bir şekilde kullanımı sağlanmakta bu sayede kırtasiyeciliğin azaltılması ve yerel ihtiyaçlarında zamanında giderilmesiyle birlikte hizmet kalitesinin de artmasına firsat tanınmaktadır (Yüksel, 2005: 254-257). Sosyal ağlar üzerinden kurum ve yöneticileri halkın nabzını daha hızlı ve kolay tutmaktadır. Örneğin; yerel yönetimlerin Twitter kullanımları, insanlarla iletişim ve hızlı işbirliği sağlamada önemli bir faktör olarak görülebilir (Tarhan, 2012; 85). Bir diğer sosyal medya uygulaması olan Instagram ise sahnenin görünen yüzü açısından oyunun kurallarını iki şekilde değiştirmiştir. Biri sahnenin arkasında olanlara ilişkin kurumu görüntüleme imkânı vermesi diğeri ise tüketicinin kuruma ilişkin olumsuz bilgilerinin hızla yayılması için kullanılması olarak görülebilir (Bergström vd., 2013: 21). $\mathrm{Bu}$ nedenle sosyal medya aracillğıyla yönetimler gerçekleşen ve yürüttükleri faaliyetleri, etkinlikleri mesaj ve duyurularını yaparak daha hızlı geri dönüşleri alabilme imkânına sahip olabildikleri gibi oluşabilecek olumsuz senaryolara da hazırlıklı olmalılar. Çünkü sosyal medya uygulamaları hızı bir avantaj olarak sunarken zaman zaman dezavantaja dönüşebilmektedir.

Türkiye'de örneklerine sıkça rastladığımız uygulamalardan biri Gençlik ve Spor Bakanlığı'nın 2018- 2022 stratejik planında sosyal medyanın stratejik plan içinde önemli bir yeri olduğu görülebilir. Sosyal medya yönetimi, sosyal medyanın etkin biçimde kullanımı, bakanlığın kurumsal kapasitesini artırmak ve çalışanların bağlılığını güçlendirmek noktasında sosyal medyanın hedef kitleye ulaşmada araç oluşu ve sosyal medya stratejilerinin yakından takibi için değerlendirmeler yapılarak hedefler belirlenmiş ve strateji planında yayınlanmıştır (http://www.sp.gov.tr/tr/stratejik-plan/s/1563/Genclik+ve+Spor+Bakanligi+2018-2022). Benzer uygulamalar ise Orman ve Su İşleri Bakanlığı, Gümrük ve Ticaret Bakanlığı, Sağlık Bakanlığı, Avrupa Birliği Bakanlığı, Ulaştırma Denizcilik ve Haberleşme Bakanlığı ve Gıda ve Tarım ve Hayvancılık Bakanlığı'nın dönem strateji planlarında sosyal medyanın da yer aldığının üstünde durulduğu bilinmektedir (Göçoğlu, 2019: 424-425). Bu örnekler Türkiye'de resmi kurumların sosyal medyayı stratejik planlar içinde profesyonel olarak alarak, sosyal medya uygulamalarının önemi noktasında farkındalık elde ettiklerine işaret etmektedir.

Araştırmaya alan oluşturan sosyal medya uygulaması olan Instagram dünyada ve Türkiye'de yaygin olarak kullanılan bir sosyal medya platformudur. Instagram kullanıcı sayısının her yıl düzenli olarak artmasıyla birlikte Facebook 2012 yılında Instagram'ı satın almıştır. Yeni uygulamaların artmasıyla birlikte 2016 yılında "hikâye" paylaşımı da eklenmiştir. Hikâye paylaşımı yapan kişiler kalıcılığ 24 saat olan paylaşımlar yapabilmektedir. Ardından anket ve link koyabilme özelliği de Instagram uygulamalarına dâhil edilmiştir. Instagram verilerine 
bakıldığında 7000 milyon kullanıcıyı içinde bulunduran popüler bir uygulama haline gelmiştir (www.instagram-press.com). 2019 yılındaki son verilere göre ise, 1 milyarı aşan kullanıcıya ulaşmıştır. Instagram sosyal ağ uygulamalarında Youtube'tan sonra en fazla kullanıcıya sahip olan uygulamadır. Instagram'da bir günde yapılan paylaşım sayısı 95 milyonu geçmektedir. Yine bir gündeki beğeni sayısı ise 5 milyar, hikâye ekleme paylaşımı ise 300 milyonu bulmaktadır. Sosyal medya platformunun önemli bir uygulaması olan Instagram kurulduğu günden bugüne geçen zamanda ise 40 milyarı aşan fotoğraf ve video paylaşımı yapılmıştır (www.brandingturkiye.com).

Dijital News Report'un 40 ülkeyi kapsayan 2019 araştırmasına göre, son yıllarda insanlar Facebook uygulamasına oranla Instagram ve Whatsapp'ı daha fazla kullanmaktadırlar. Aşağıda verilen grafikte 2014-2019 yılları arasında Dijital Report'un yaptığı araştırmaya göre haftalık olarak herhangi bir amaçla sosyal medya kullanım oranları verilmiştir.

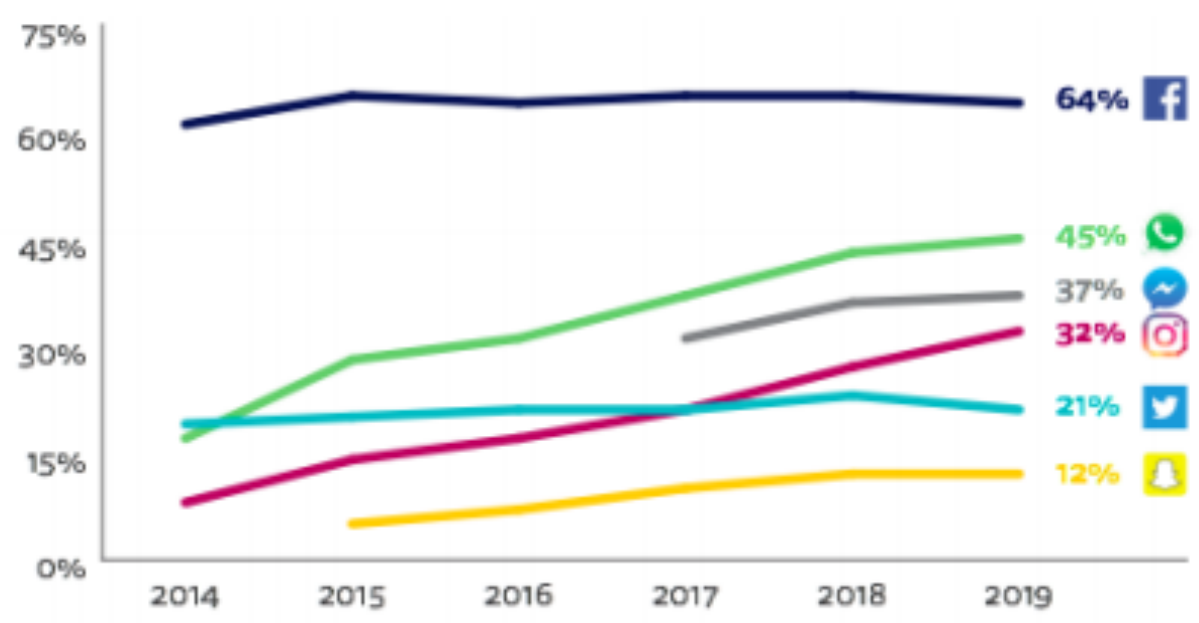

Grafik 1: Herhangi Bir Amaçla Haftalık Sosyal Medya Kullanımı.

Kaynak: Dijital News Report 2019

Grafik 1'de haftalık sosyal medyanın herhangi bir amaç doğrultusunda kullanımı gösterilmektedir. 2014-2019 yılları arasında yapılan araştırmaya göre; Facebook (\%64) tercih edilen sosyal medya aracı olduğu görülmektedir. Fakat son 6 yılın oranlarına bakıldığında düşüş gerçekleştiği görülmektedir. Aynı şekilde Twitter (\%21) uygulamasının kullanım oranın da düştüğü görülmektedir. Whatsapp (\%45), Messenger (\%37), Snapchat (\%12) uygulamaların kullanım oranları artmıştır. Özellikle Instagram (\%32) uygulamasının giderek artan bir grafiğinin olduğu görülmektedir.

Aşağıda gösterilen grafik 2' de 2014-2019 yılları arasında Dijital Report'un yaptığı bir araştırmaya göre haftalık olarak haber kaynaklarının sosyal medya uygulamaları tarafından kullanım oranları gösterilmektedir. Bu grafiğe göre haftalık olarak haber kaynağı kullanımında sosyal medya oranları gösterilmektedir. 2014-2019 yılları arasındaki yapılan bu araştırmaya göre; Facebook (\%36) halen birincil haber kaynağı olmakla birlikte son yıllarda düşüş yaşandığ1 görülmüştür. Haber kaynağı olarak kullanılan diğer sosyal medya uygulamalarında ise Whatsapp'ın (\%16) son yıllarda yükselişte olduğu, Twitter'ın (\%10) düşüşte olduğu, Instagram'ın (\%9) ile yükselişte olduğu, Messenger'ın (\%8) yükselişte olduğu ve Snapchat'in (\%3) ise düşüşte olduğu görülmektedir. 


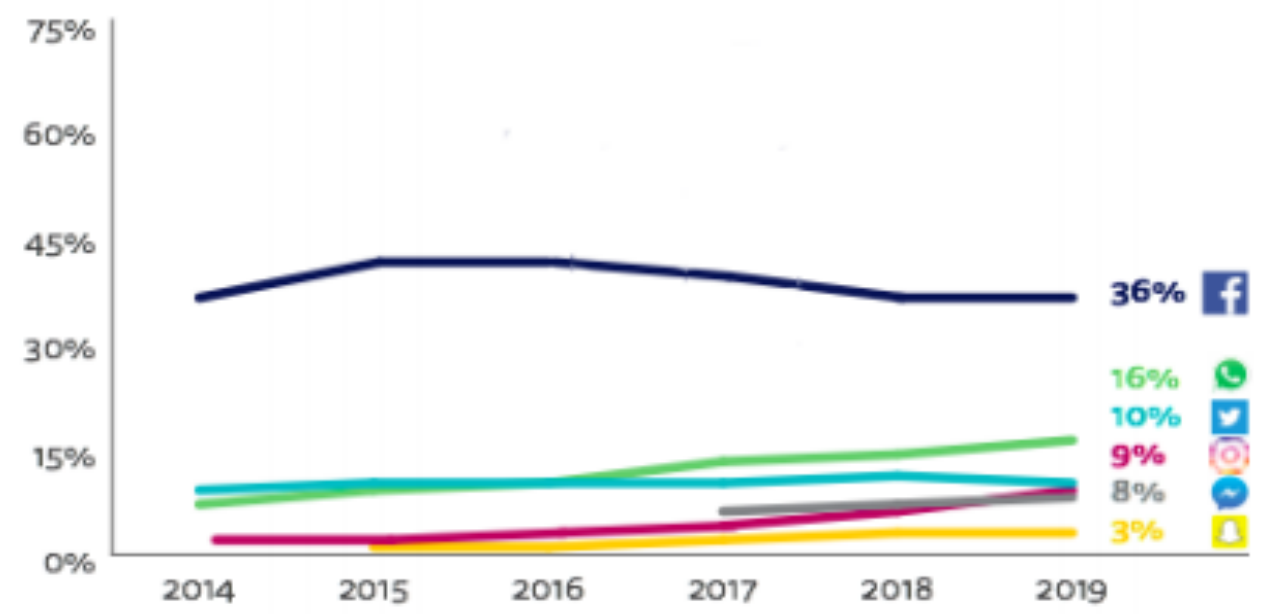

Grafik 2: Haber Kaynağı Olarak Haftalık Sosyal Medya Kullanımı

Kaynak: Dijital News Report 2019

Instagram günümüzde kişilerin sadece fotoğraf, video vb. içerikleri paylaştığ bir platform olmamakla birlikte iyi bir halkla ilişkiler uygulama alanıdır. Kullanıcılarının yoğun olduğu bu uygulama kurumların hizmetlerini, ürünlerini daha yakından tanıyabilmektedir. Instagram kullanıcılarına doğal bir ortam sunarak çeşitli paydaş gruplarına da kolaylıkla ulaşabilmektedir. Paydaşların birebir uygulamalara tanıklık etmeleri kurum-paydaş ilişkilerini de güçlendirmektedir. Instagram, Dijital News Report 2019 raporunda gösterildiği üzere son zamanlarda haber kaynağı olarak da kullanımın arttığı görülmektedir.

Devlet kuruluşlarının da diğer kurumlar gibi gerçekleştirdikleri faaliyetleri kamuya tanıtma ve etkileşimleri alabilme amacıyla sosyal medya kullanımlarını artırdıkları yapılan incelemelerde değerlendirilmiştir. Bu doğrultuda Covid 19 süreci içinde Sağlık Bakanlığı'nın bu küresel krize ilişkin geliştirildiği bilgilendirme çalışmalarının kurumun web sayfasının yanı sıra sosyal medya uygulamaları üzerinden de gerçekleştirdiği görülmektedir. Bir diğer değerlendirme ise Dr. Fahrettin Koca' nın resmi Twitter hesabından yapılan paylaşımlarla senkronize/eş zamanlı olarak Instagram uygulamasından paylaşım yapıldığının tespitidir.

\section{ARAŞTIRMANIN METODOLOJISİ}

Bu bölümde araştırmanın metodolojisine ilişkin detaylı bilgiler başlıkların altında derlenerek verilmiştir.

\section{Araştırmanın Konusu}

Kamuyu bilgilendirme modeli çerçevesinde Covid-19 sürecinde Dr. Fahrettin Koca'nın resmi Instagram hesabı üzerinden paylaşılan gönderilerin analiz edilmesi ve kamunun bu hesaptan paylaşılan gönderilere karşı etkileşim pratiklerinin değerlendirilmesidir.

\section{Araştırmanın Amacı}

2019 yılı sonunda Çin'de başlayarak tüm dünyayı etkisi altına alan Covid-19 salgınının her ülkenin kendi sosyo-ekonomik ve politik çerçevesinde farklı biçimlerde yönetilmesine ortam hazırlamıştır. Bu noktada Türkiye, kaynağı henüz tam olarak belirlenememiş bu virüse karşı bir hareket planı hazırlayarak yürürlüğe kademeli olarak sokmuştur. Bu noktadan hareketle küresel krizin ülkemizdeki yansımaları özellikle sağlık sektörünün başrol haline gelmesine neden olmuştur. Sağlık Bakanı Dr. Fahrettin Koca bu süreçte düzenli olarak kamuyu bilgilendirici 
toplantılar yapmış ve bu noktada kamudan takdir toplamıştır. Eş zamanlı olarak Dünya Sağlık Örgütü Genel Direktörü, Türkiye'yi yakından takip eden bir bilim adamı olarak Dr. Fahrettin Koca'yı Twitter üzerinden takibe alarak, Türkiye'de yapılan çalışmalarının başarısına ilişkin görüş bildirmiştir (https://www.aa.com.tr/tr/turkiye/dso-genel-direktoru-ghebreyesus-saglikbakani-kocayi-sosyal-medyada-takibe-aldi/1825274).

Kitle iletişim araçlarının yanı sıra sosyal medya üzerinden düzenli bilgilendirilmelerin gerçekleştiği bu süreçte, bu çalışma ile Sayın Koca'nın resmi Instagram hesabının nasıl yönetildiğinin, bu bağlamda kamuyu bilgilendirmeler sırasında sosyal medyada nasıl bir strateji izlediğinin ortaya konması amaçlanmaktadır. Bu çalışma ile süreç kayıt altına alınarak ileriki dönemlerde resmi kurum ve kuruluşların ve kuruluşların liderlerinin kamuyu bilgilendirmenin önemine ilişkin dikkatlerinin çekilmesi umulmaktadır.

Bu çalışmada kamuyu bilgilendirme aracı olarak kullanılan Instagram'ın değerlendirilmesinin yanı sıra Dr. Fahrettin Koca'nın resmi Instagram hesabından paylaşılan gönderilere kamunun gösterdiği etkileşimler de analiz edilerek bulguların literatüre kazandırılması hedeflenmektedir.

\section{Araştırmanın Yöntemi}

Araştırmanın yöntemi içerik analizidir. İçerik analizi yapılırken ne, nasıl, kime sorularından en az biri yantllanmaya çalışılır. (Tavşancıl ve Aslan: 2001: 33). Bu çalışmada kategoriler üzerinde paylaşılan içeriklerin "ne" olduğuna ilişkin bir sınıflandırma yapılması hedeflenmektedir. İçerik analizi yöntemi, istatistiki veriler kullanılarak elde edilen veriler üzerinden yorum imkânı sağlar. İstatistiki verilerin kullanımı, araştırmacının sistematik ve objektif bir yorum yapabilmesini sağlar (Koçak ve Arun, 2006, 24).

Çalışmada uygulanacak olan içerik analizi yönteminin kategorileri oluşturulurken Kamuyu Bilgilendirme Modeli çerçevesinde kurumların ya da kişilerin bilgilendirmeleri hangi niteliklerle paylaştıkları detaylandırılarak belirlenmesine dikkat edilmiştir. Bu noktadan hareketle kategorilerin tanımları uzman iki akademisyenden de görüş alınarak oluşturulmuştur. Buna göre kamuyu bilgilendirme, özel gün/anma/teşekkür, eğitici/öğretici görsel, kurum etkinliği, dezenformasyon düzeltme, kamu spotu ve diğer olmak üzere 7 kategori oluşturulmuştur. Bu kategorilerin tanımları örnekler ile aşağıda detaylandırılmıştır.

Kamuyu Bilgilendirme: Kamunun bilgilendirilmesi amacıyla paylaşılan gönderilerin kaydedildiği kategoridir. Dr. Fahrettin Koca Instagram hesabı üzerinden özellikle basın toplantılarından kesitlerin verildiği gönderiler, günlük vaka rakamlarının aktarıldığı tabela gönderiler ve bilgilendirme amacıyla Dr. Fahrettin Koca'nın Twitter hesabından paylaşılan bilgilendirme twit-lerinin ekran görüntülerinin yer aldığı gönderiler bu kategoride yer almaktadır.

Özel Gün-Anma-Teşekkür: Hesap üzerinden paylaşılan özel gün kutlama mesajları içeren gönderiler, vefat nedeniyle taziye mesajları ve anma içerikli gönderiler ile teşekkür niteliğinde yayınlanan mesajlar bu kategoride kayıt altına alınmıştır. Bu noktada örnek olarak Covid -19 mücadelesinde yaşamını yitiren hekimlere ilişkin anma ve taziye mesajlarının yanı sıra görevi nedeniyle aktif saha görevlerinde çalışmak durumunda kalanlar için yayınlanan teşekkür mesajları da verilebilir.

Eğitici-Öğretici Görsel: Sağllk Bakanlığı tarafından toplumun Covid-19'a ilişkin bilinçlendirilmesi ve alınan önlemlere ilişkin farkındalık yaratılmasına yönelik hazırlanan 
görseller bu kategoride ele alınmıştır. Bu noktada örnek olarak "14 Gün Kuralı" gönderileri verilebilir.

Kurum Etkinliği: Sağlık Bakanlığı görevini yürüten Sayın Dr. Fahrettin Koca'nın katıldığı toplantılar, denetleme etkinlikleri gibi faaliyetlerin yer aldığı gönderiler bu kategori altına kaydedilmiştir. Bu noktada diğer bakanlıklar ile yapılan istişare toplantılarının içerik olarak paylaşılması örnek olarak verilebilir.

Dezenformasyon Düzeltme: Sosyal medya ortamı üzerinden bilgi akışlarının hızlı olması nedeniyle zaman zaman avantajın dezavantaja dönüşmesi "sahte haber", "gerçek dışı haber" niteliğindeki haberlerin de yayılımını ve kamuoyunun oluşması üzerinde etki yarattığı bilinmektedir (Çömlekçi, 2019: 1550). Bu noktadan hareketle analize alınana Dr. Fahrettin Koca Instagram hesabı üzerinden bilginin düzeltilmesi, dezenformasyonun (bilgi çarpıtma) giderilmesi amacıyla paylaşılan gönderiler bu kategoride kayıt altına alınmıştır. Bu noktada Sayın Bakan'ın özellikle Yurt dışından ülkeye ambulans uçaklarla getirilen hastalara ilişkin verdiği değerlendirme bilgileri örnek verilebilir.

Kamu Spotu: Kamu Spotları yönergesinin 3b maddesinde "Kamu kurum ve kuruluşları ile dernek ve vakıf gibi sivil toplum kuruluşlarınca hazırlanan veya hazırlatılan ve Üst Kurul tarafından yayınlanmasında kamu yararı olduğuna karar verilen bilgilendirici ve eğitici nitelikteki film ve sesler ile alt bantları" (https://www.rtuk.gov.tr/spot-filmler/3717/3985/kamuspotlari-yonergesi.html) ifadesiyle tanımlanmıştır. Kamu spotlarının sosyal medya üzerinden yayınlanması yoluyla paylaşılan gönderiler bu kategori altında kayıt altına alınmıştır. Eş zamanlı olarak televizyon yayınlarında da yer alan bu kamu spotları Sağlık Bakanlığı tarafından kamuoyu üzerinde farkındalık yaratmak amacıyla yayınlanan kısa filmlerdir. 14 gün kuralının açılanması amacıyla hazırlanarak yayınlanan kamu spotları bu kategoriye örnek olarak verilebilir.

Diğer: Yukarıda belirtilen kamuyu bilgilendirme amacıyla yayınlanan gönderiler dışında kalan ve hiçbir kategoriye dâhil olmayan gönderiler ise bu kategoriye kaydedilmiştir. Buna örnek olarak "Biz Bize Yeteriz Kampanya" görseli ve "Gecenin Fotoğrafı" ifadesiyle paylaşılan Cumhurbaşkanı Recep Tayyip Erdoğan'ın fotoğrafı diğer kategorisi içinde kaydedilen gönderiler olarak gösterilebilir.

Çalışma dâhilinde analizi gerçekleştirilen gönderilerin aynı zamanda beğeni ve yorum rakamları da kayıt altına alınarak, kamunun gönderilere ne oranda etkileşim gösterdiği de görece olarak ortaya konmaya çalışılacaktır. Bu noktada kategori bazında beğeni ve yorum rakamları, gönderi rakamları ile aritmetik ortalamalar ile değerlendirilerek sonuçlar derlenecek ve yorumlanacaktır. Aynı gün içinde birden fazla gönderi paylaşılan günlerde elde edilen beğeni ve yorum rakamları kendi kategorilerinde toplanarak aritmetik ortalamaları belirlenerek değerlendirilmeye alınmıştır.

\section{Araştırmanın Örneklemi}

Çalışma Türkiye Cumhuriyeti Sağlık Bakanı Dr. Fahrettin Koca'nın Instagram hesabı üzerinden Covid-19 sürecinde yaptığı paylaşımları analiz etmeyi hedeflemektedir. Dr. Fahrettin Koca twitter hesabı, bu dönemde Sağlık Bakanlığı verileri ile eş zamanlı paylaşımlar ile bu kanal da kullanılarak duyurulduğundan araştırma örneği olarak ele alınmıştır. Bu noktada Türkiye' de ilk Covid-19 vaka tespiti olan 11 Mart 2020 esas alınmış ve Mart ayının başından itibaren analiz kümesine dâhil edilerek 01 Mart 2020-30 Nisan 2020 tarihleri arasında bahsi geçen hesaptan 
yayınlanan gönderiler örneklem kümesini oluşturulmuştur. Buna göre bu tarihler arasında Dr. Fahrettin Koca'nın resmi Instagram hesabı üzerinden toplam olarak 286 gönderi paylaşılmıştır. Hesabın künye görseli aşağıda yer almaktadır.
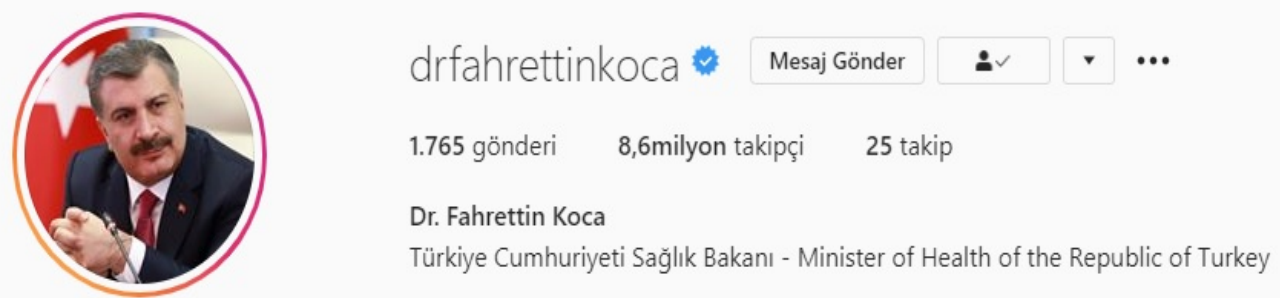

Görsel 1: Dr. Fahrettin Koca Resmi Instagram Sayfası künyesi

Dr. Fahrettin Koca'nın resmi Instagram sayfasının araştırmanın gerçekleştirildiği süreçte toplam takipçi rakamı 8.612.302 ve toplam takip ettiği hesap sayısı 25 olarak kayıt altına alınmıştır. Bahsi geçen hesaptan analizin yapıldığı gün dâhilinde toplam olarak 1.732 gönderi paylaşıldığı belirlenmiştir. Hesap tanımında "Türkiye Cumhuriyeti Sağlık Bakanı-Minister of Health of the Republic of Turkey" yazmaktadır.

\section{Araştırmanın Sinırlılıkları}

Çalışma özellikle Covid-19 süreci ile güncel hale gelen Sağlık Bakanı Dr. Fahrettin Koca'nın sosyal medya hesaplarından Instagram üzerinden faaliyetlerini analiz etmeyi hedeflemiştir. Kamuyu Bilgilendirme Modeli çerçevesinde analiz gerçekleştirilmiş bu noktada analiz verilerin gün-gün değişebilme ihtimaline karşın bir gün içinde tek kodlayıcı tarafından kayda alınmıştır. Araştırmanın analiz için kodların kayda alınma tarihi 02.05.2020'dir.

Bir diğer sınırlılık Kamuyu Bilgilendirme Modeli kurumlar için değerlendirilen bir model iken bu çalışma kapsamında Sağlık Bakanının resmi hesabından yaptığı paylaşımlar model çerçevesinde değerlendirilmiştir. Bu noktada küresel bir krizin ulusal yansımaları boyutundan Sağlık Bakanlı̆̆ı'nın temsilcisi olarak Dr. Fahrettin Koca kurum ile özdeşleşen bir aktör haline gelmiş bu bağlamda bakanlık nezdinde tüm açıklamalar eş zamanlı olarak şahsi hesabı üzerinden de verilmiştir.

\section{BULGULAR}

Çalışmada öncelikli olarak 1 Mart 2020-30 Nisan 2020 tarihleri arasında paylaşılan gönderilerin kategoriler üzerinden analizi gerçekleştirilmiştir. Bu bağlamda kamuyu bilgilendirme, özel gün/anma/teşekkür, eğitici/öğretici görsel, kurum etkinliği, dezenformasyon (bilgi çarpıtma) düzeltme, kamu spotu ve diğer kategorileri altına tüm gönderiler sınıflandırılarak kayıt altına alınmıştır buna göre belirtilen tarihler arasında Dr. Fahrettin Koca'nın resmi Instagram hesabı üzerinden toplam olarak 286 gönderi paylaşıldığ kayıt altına alınmıştır.

Gönderilerin 157 frekans ile en yüksek yüzde ile \%54,90 oran ile kamuyu bilgilendirme kategorisinin oluşturduğu aşağıdaki tablodan görülmektedir. 35 frekans ile özel gün/anma ve teşekkür içerikli gönderiler tüm gönderilerin \%12,24'ünü oluşturmaktadır. Üçüncü sırada ise sağlık Bakanlığı tarafından hazırlatılan eğitici/öğretici görsellerin 29 frekans \%10,14 oran ile paylaşıldığı kayıt altındadır. Daha sonra kurum etkinliği olarak Bakanın yaptığı toplantılar ve görüşmelere ilişkin paylaşılan gönderiler 25 frekans \%8,74 oran ile görülmektedir. Bir diğer kategori olan dezenformasyon düzeltme gönderilerinin 20 frekans $\% 6,99$ oran ile, kamu spotu gönderilerimim 14 frekans \%4,90 oran ile ve diğer kategorisinin 6 frekans \%2,10 oran ile paylaşıldığı aşağıdaki tabloda yer almaktadır. 
Tablo 1: 01 Mart - 30 Nisan 2020 Tarihleri Arasında Paylaşılan Gönderilerin Kategori Analizi Tablosu

\begin{tabular}{lll}
\hline Kategori & Frekans & Oran \\
\hline Kamuyu Bilgilendirme & 157 & $\% 54,90$ \\
Özel Gün/Anma/Teşekkür & 35 & $\% 12,24$ \\
Eğitici/Öğretici Görsel & 29 & $\% 10,14$ \\
Kurum Etkinliği & 25 & $\% 8,74$ \\
Dezenformasyon Düzeltme & 20 & $\% 6,99$ \\
Kamu Spotu & 14 & $\% 4,90$ \\
Diğer & 6 & $\% 2,10$ \\
TOPLAM & $\mathbf{2 8 6}$ & $\mathbf{0 1 0 0}$ \\
\hline
\end{tabular}

Yukarıda belirtilen bu verilere göre özellikle Sayın Bakan'ın Instagram hesabından basın toplantısı görüntülerinin yer aldığı bilgilendirme videoları ve günlük olarak vaka rakamlarının belirtildiği gönderilerin paylaşımının tüm gönderiler içinde en yüksek orana sahip olduğu kayıt altındadır. \%54,90 oran ile Dr. Fahrettin Koca'nın resmi Instagram hesabından en yüksek bu bağlamda belirtilmesi gereken nokta şudur ki; kamu spotu, eğitici/öğretici görseller, dezenformasyon düzeltme ve kurum etkinliği gönderileri de dolaylı olarak kamuyu bilgilendirme amacı taşımakla birlikte bu gönderiler kamudaki "farkındalığı artırmaya" yönelik çalışmalar olarak değerlendirilebilir. Bu nedenle amacı dolaysız olarak kamuyu bilgilendirmeye yönelik olan gönderiler diğerlerinden ayrı bir biçimde değerlendirilmiştir. Sonuç olarak özellikle kamuda farkındalık arttırmaya yönelik bilgilendirme gönderileri en sık paylaşılan gönderiler olarak belirlenmiştir.

Çalışmanın diğer basamağında her bir gönderinin beğeni ve yorum rakamları 02.05.2020 tarihinde kayıt altına alınmıştır. Bu noktadan hareketle kategoriler bazında beğeni ve yorum rakamları toplamı ortaya konmuştur. Aynı zamanda gönderi başına etkileşim oranını görebilmek için aritmetik ortalamalar alınmış ve aşağıdaki tabloda rakamlar verilmiştir. Tablonun değerlendirmesi aşağıda bulunmaktadır.

Tablo 2: Kategorilerin Beğeni ve Yorum Rakamları ve Kullanıcı Etkileşim Rakamları

\begin{tabular}{lllll}
\hline Kategori & $\begin{array}{l}\text { Toplam } \\
\text { Beğeni Sayısı }\end{array}$ & $\begin{array}{l}\text { Gönderi } \\
\text { Başına } \\
\text { Etkileşim }\end{array}$ & $\begin{array}{l}\text { Toplam } \\
\text { Yorum Sayıs1 }\end{array}$ & $\begin{array}{l}\text { Gönderi } \\
\text { Başına } \\
\text { Etkileşim }\end{array}$ \\
\hline Kamuyu Bilgilendirme & 46.685 .184 & 297.357 & 906.470 & 5.774 \\
Özel Gün/Anma/Teşekkür & 19.655 .054 & 561.573 & 181.823 & 5.194 \\
Eğitici/Öğretici Görsel & 7.913 .547 & 272.880 & 65.665 & 2.264 \\
Kurum Etkinliği & 8.715 .481 & 348.619 & 128.283 & 5.131 \\
Dezenformasyon Düzeltme & 3.222 .060 & 161.103 & 46.782 & 2.339 \\
Kamu Spotu & 2.207 .533 & 157.681 & 22.227 & 1.587 \\
Diğer & 1.278 .992 & 213.165 & 33.336 & 5.556 \\
TOPLAM & 89.677 .851 & ---- & 1.384 .586 & ---- \\
\hline
\end{tabular}


Kayıt altına alınan 286 gönderi toplam olarak 89.677 .851 beğeni almıştır. Toplam beğeni rakamı verisine bakıldığında en fazla beğeni alan kategoriden en az beğeni alan kategoriye doğru; kamuyu bilgilendirme kategorisi, özel gün/anma/teşekkür kategorisi, kurum etkinliği kategorisi, eğitici/öğretici görsel kategorisi, dezenformasyon düzeltme kategorisi, kamu spotu kategorisi ve diğer kategorisi sırasıyla kayıt altındadır. Bu noktada gönderilerin de fazla olduğu kategori olan kamuyu bilgilendirme kategorisinde gönderi başına düşen beğeni rakamına bakıldığında ise birinci sırada olmadığı görülmektedir. Aritmetik ortalamaya göre kamuyu bilgilendirme kategorisi toplam 49.685 .184 beğeni almış iken gönderi başına 297.357 beğeni aldığ1 aritmetik ortalama ile değerlendirilmiştir. İkinci sırada yer alan özel gün/anma/teşekkür kategorisi toplam olarak 19. 655.054 toplam beğeni rakamına sahip olmasına karşın gönderi başına etkileşim noktasında 561.573 beğeni rakamı ile kategoriler içinde kamunun en fazla etkileşim gösterdiği kategori olarak belirlenmiştir. Gönderilerin kayıt altına alınan beğeni rakamlarının aritmetik ortalamaları dikkate alınarak bir sırlama yapıldığında kamunun birinci sırada özel gün/anma/teşekkür kategorisi daha sonra ise sırasıyla kurum etkinliği kategorisi, kamuyu bilgilendirme kategorisi, eğitici/öğretici görsel kategorisi, diğer kategorisi, dezenformasyon düzeltme kategorisi ve son olarak kamu spotu kategorisine etkileşim gösterdiği görülmektedir. $\mathrm{Bu}$ noktada veriler içinde dikkate değer biçimde değerlendirilmesi gereken diğer kategorisi içinde yer alan Cumhurbaşkanı Sayın Recep Tayyip Erdoğan'ın görsellerinin paylaşıldığı gönderilere karşı kullanıcıların etkileşim gösterdiği de tablodan görülebilmektedir.

01 Mart-30 Nisan 2020 tarihleri arasında kayıt altına alınan gönderiler toplam olarak 1.384.586 yorum almıştır. Paylaşılan 286 gönderiye kullanıcılar tarafından yapılan yorum rakamlarına kategoriler bazında bakıldığında ise yine en fazla gönderinin paylaşıldığı kategori olan kamuyu bilgilendirme kategorisinde 906.470 yorum sayısı ile aynı kategori birinci sırada yer almaktadır. Gönderi başına etkileşim rakamlarına bakıldığında ise kamu bilgilendirme gönderilerine kullanıcılar tarafından 5.774 rakam ile gönderi başına etkileşim gösterdiği aritmetik ortalama ile değerlendirilmiştir. Diğer yandan diğer kategorisinde yer alan 6 gönderiye ise kullanıcılar tarafından gönderi başına 5.556 yorum yazılarak kullanıcı etkileşimleri sıralamasında diğer kategorisinin ikinci sırada yer almıştır. Bu noktada belirtilmesi gereken bir diğer tespit kullanıcıların Cumhurbaşkanı Recep Tayyip Erdoğan'ın görsellerine karşı duyarlı olduğudur. Bu nedenle yorum etkileşim rakamlarının yüksek olduğu da ayrı bir değerlendirme olarak kayıt altına alınmıştır. Kullanıcılar özel gün/anma/teşekkür gönderilerine karşı beğenme rakamlarında olduğu gibi yorum etkileşim rakamlarında da duyarlılık göstermiş ve bu gönderilere 5.194 aritmetik ortalama ile gönderi başına yorum yapmışır. Daha sonra ise sırasıyla dezenformasyon düzeltme 2.339 etkileşim, eğitici öğretici görsel kategorisine 2.264 ve kamu spotu gönderilerine 1.587 gönderi başına aritmetik ortalama ile etkileşim göstermiştir.

Çalışmanın bir diğer değerlendirmesi beğeni ve yorum rakamlarının gün bazlı değerlendirilmesidir. Kayıt altına alınan beğeni ve yorum rakamları gün bazında değerlendirilirken aynı gün içinde paylaşılan gönderilerin beğeni rakamları toplanarak gönderi rakamı ile aritmetik ortalaması alınmış bu biçimde değerlendirildiği gün için yanıltıcı olmaması ve gün gün değerlendirilebilmesi amacıyla her gün için tek bir beğeni rakamı değerlendirmeye alınmıştır. Bu bağlamda aşağıdaki tabloda gün gün kayıt rakamları yer almaktadır.

Aşağıdaki tabloda görülebileceği gibi 01 Mart 2020 tarihinde 8.279 beğeni rakamı ile başlayan değerler özellikle 11 Mart 2020 tarihinde ilk vakanın duyurulmasının ardından katlanarak artış göstermiştir. 15 Mart 2020'de 52.027, 31 Mart 2020 256.057, 15 Nisan 2020'de 238.330 ve 30 Nisan 2020 'de 346.631 olarak kaydedilmiştir. Beğeni rakamlarının gün bazlı aritmetik ortalamaları incelendiğinde 26.04.2020 tarihinde 885.616 rakamına kadar ulaştığı görülmektedir. Bu noktadan 
hareketle kamunun yükselen bir ivme ile hesaptan paylaşılan gönderilere gün gün etkileşiminin artığını söylemek yerinde olacaktır. Bu da kamuyu bilgilendirme aracı olarak tercih edilen Instagram uygulaması gönderilerinin kamuya ulaşarak hedeflenen amacı gerçekleştirdiğini ortaya koymaktadır. Kısaca Instagram kamuyu bilgilendirme aracı olarak hedef kitleye ulaşmıştır.

Tablo 3: Tarih Bazında Beğeni Rakamı Aritmetik Ortalama Tablosu

\begin{tabular}{llllll}
\hline Tarih & Beğeni & Tarih & Beğeni & Tarih & Beğeni \\
\hline 1.03 .2020 & 8.729 & 22.03 .2020 & 477.289 & 12.04 .2020 & 434.277 \\
2.03 .2020 & 5.883 & 23.03 .2020 & 594.530 & 13.04 .2020 & 708.909 \\
3.03 .2020 & 4.107 & 24.03 .2020 & 290.264 & 14.04 .2020 & 255.639 \\
4.03 .2020 & 6.024 & 25.03 .2020 & 482.259 & 15.04 .2020 & 238.330 \\
5.03 .2020 & 5.953 & 26.03 .2020 & 262.398 & 16.04 .2020 & 495.062 \\
6.03 .2020 & 10.226 & 27.03 .2020 & 403.857 & 17.04 .2020 & 534.939 \\
7.03 .2020 & 8.013 & 28.03 .2020 & 335.698 & 18.04 .2020 & 362.857 \\
8.03 .2020 & 11.435 & 29.03 .2020 & 382.976 & 19.04 .2020 & 450.237 \\
9.03 .2020 & 6.903 & 30.03 .2020 & 452.413 & 20.04 .2020 & 690.918 \\
10.03 .2020 & 11.103 & 31.03 .2020 & 256.057 & 21.04 .2020 & 512.372 \\
11.03 .2020 & 38.659 & 1.04 .2020 & 448.905 & 22.04 .2020 & 457.183 \\
12.03 .2020 & 15.826 & 2.04 .2020 & 264.474 & 23.04 .2020 & 362.008 \\
13.03 .2020 & 25.164 & 3.04 .2020 & 421.592 & 24.04 .2020 & 848.869 \\
14.03 .2020 & 26.638 & 4.04 .2020 & 380.259 & 25.04 .2020 & 800.268 \\
15.03 .2020 & 52.027 & 5.04 .2020 & 563.128 & 26.04 .2020 & 885.616 \\
16.03 .2020 & 125.467 & 6.04 .2020 & 430.960 & 27.04 .2020 & 761.238 \\
17.03 .2020 & 178.537 & 7.04 .2020 & 458.994 & 28.04 .2020 & 696.881 \\
18.03 .2020 & 247.974 & 8.04 .2020 & 292.738 & 29.04 .2020 & 333.539 \\
19.03 .2020 & 337.816 & 9.04 .2020 & 382.666 & 30.04 .2020 & 346.631 \\
20.03 .2020 & 387.494 & 10.04 .2020 & 567.935 & ---- & --- \\
21.03 .2020 & 350.618 & 11.04 .2020 & 331.936 & ---- & ---- \\
\hline & & & & &
\end{tabular}

Yukarıda belirtilen beğeni aritmetik ortalamalarının gün gün değerlendirmesinin daha açık bir biçimde görülebilmesi için aşağıda gün bazlı beğeni sayısı grafiği oluşturulmuştur. Bu noktadan hareketle yükselen beğeni rakamları grafik üzerinden de net bir biçimde görülebilmektedir. Bu değerlendirme de kamunun hesaptan paylaşılan gönderilere etkileşimin arttığını ortaya koymaktadır. 


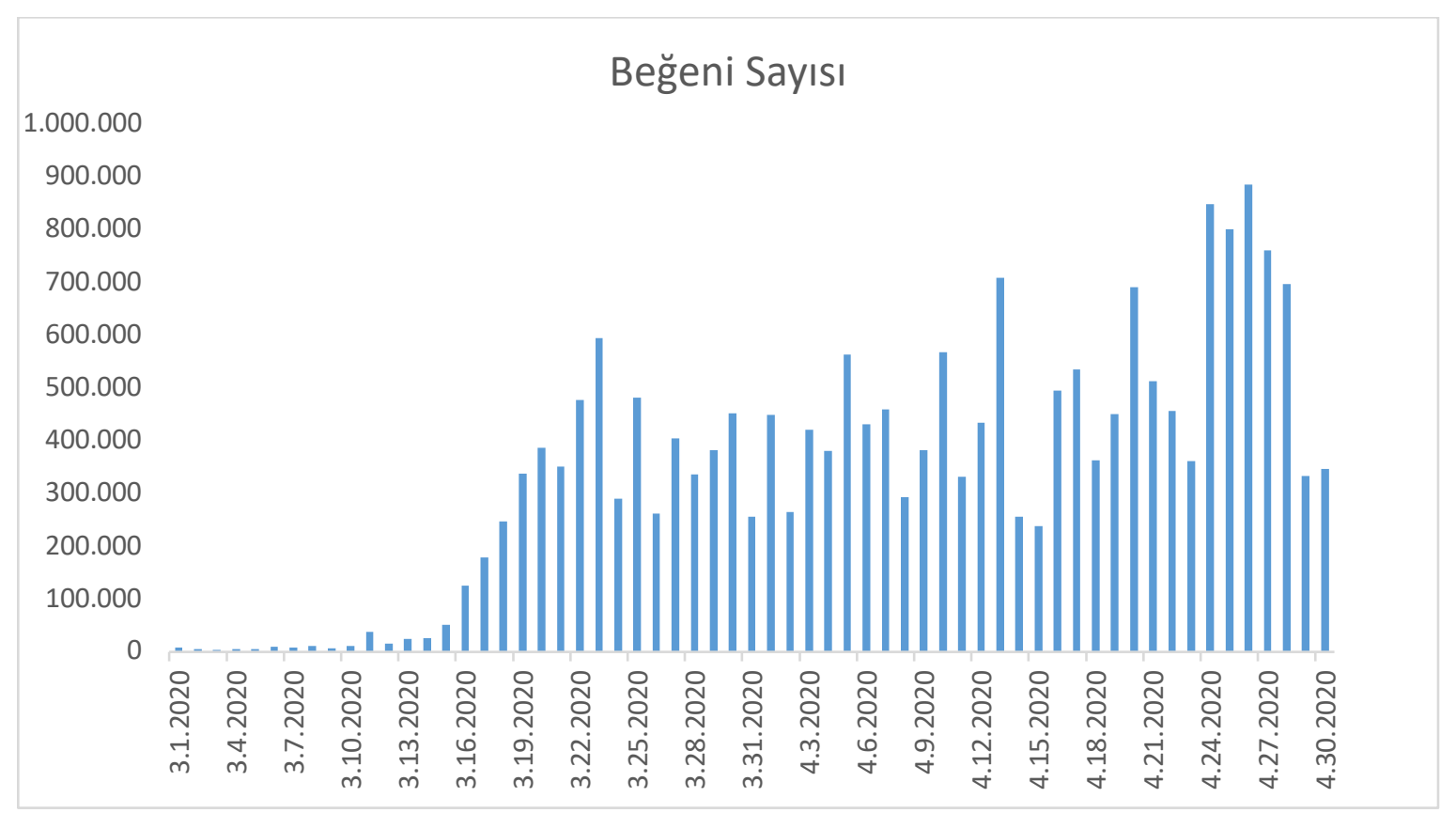

Grafik 3: Beğeni Rakamlarının Gün Bazlı Değerlendirilmesi

Tablo 4: Tarih Bazında Yorum Rakamı Aritmetik Ortalama Tablosu

\begin{tabular}{llllll}
\hline Tarih & Beğeni & Tarih & Beğeni & Tarih & Beğeni \\
\hline 1.03 .2020 & 98 & 22.03 .2020 & 8.588 & 12.04 .2020 & 5.516 \\
2.03 .2020 & 106 & 23.03 .2020 & 13.705 & 13.04 .2020 & 7.999 \\
3.03 .2020 & 88 & 24.03 .2020 & 4.008 & 14.04 .2020 & 2.525 \\
4.03 .2020 & 293 & 25.03 .2020 & 8.643 & 15.04 .2020 & 3.162 \\
5.03 .2020 & 128 & 26.03 .2020 & 11.078 & 16.04 .2020 & 6.012 \\
6.03 .2020 & 295 & 27.03 .2020 & 9.185 & 17.04 .2020 & 7.370 \\
7.03 .2020 & 97 & 28.03 .2020 & 6.363 & 18.04 .2020 & 3.967 \\
8.03 .2020 & 310 & 29.03 .2020 & 16.731 & 19.04 .2020 & 5.688 \\
9.03 .2020 & 110 & 30.03 .2020 & 8.988 & 20.04 .2020 & 6.555 \\
10.03 .2020 & 523 & 31.03 .2020 & 11.437 & 21.04 .2020 & 7.326 \\
11.03 .2020 & 492 & 1.04 .2020 & 16.286 & 22.04 .2020 & 4.130 \\
12.03 .2020 & 481 & 2.04 .2020 & 4.489 & 23.04 .2020 & 2.478 \\
13.03 .2020 & 702 & 3.04 .2020 & 5.326 & 24.04 .2020 & 8.489 \\
14.03 .2020 & 709 & 4.04 .2020 & 4.909 & 25.04 .2020 & 9.150 \\
15.03 .2020 & 1.973 & 5.04 .2020 & 9.084 & 26.04 .2020 & 13.644 \\
16.03 .2020 & 4.209 & 6.04 .2020 & 4.774 & 27.04 .2020 & 7.894 \\
17.03 .2020 & 4.790 & 7.04 .2020 & 4.832 & 28.04 .2020 & 6.899 \\
18.03 .2020 & 8.633 & 8.04 .2020 & 3.488 & 29.04 .2020 & 3.265 \\
19.03 .2020 & 9.101 & 9.04 .2020 & 6.442 & 30.04 .2020 & 2.389 \\
20.03 .2020 & 12.107 & 10.04 .2020 & 10.475 & --- & ---- \\
21.03 .2020 & 6.231 & 11.04 .2020 & 3.779 & ---- & ---- \\
\hline
\end{tabular}


Tabloda görülebileceği gibi 01 Mart 2020 tarihinde 98 yorum rakamı ile başlayan değerler özellikle 15 Mart 2020 tarihinden itibaren artış göstermiştir. Bu tabloda 20.03.2020 tarihinde görülen 12.107 aritmetik ortalama ile yorum rakamı incelendiğinde günlük vaka tablosuna takipçilerin yorum yaptıkları belirlenmiştir. 10.04.2020 tarihinde görülen 10.475 aritmetik ortalama ile belirlenen yüksek yorum rakamı ise sokağa çıkma kısıtlamasının akşam saatlerinde duyurulması sonucu kullanıcıların bu akşam paylaşılan gönderiler altına yorum yapması nedeniyle yüksek kaydedilmiştir. Bir diğer dikkat çekici değer ise 26.04.2020 tarihindeki gönderilere gelen 13.644 aritmetik ortalama ile kayda alınan yorum rakamıdır. Bu tarihte paylaşılan gönderiler incelendiğinde İsveç'ten Türkiye'ye getirilen Türk vatandaşına ilişkin bilgilendirmelerin gerçekleştĭği gönderiler olduğu da kaydedilmiştir. Bu veriler ışığında kamunun gönderilere beğeni ile etkileşim göstermesi ile yorum ile etkileşim göstergesi arasında anlamlı bir ilişki görülmemektedir. Diğer yandan kullanıcıların gönderilerin içeriğine bağlı olarak yorum yaptıkları belirtilebilir.

Yukarıdaki tabloda belirtilen aritmetik ortalamaları alınan yorum rakamlarının grafik biçiminde değerlendirilmesi aşağıda yer almaktadır. Her ne kadar yorum rakamları beğeni rakamları kadar yükselen ivmede görülmese de özellikle 15 Mart 2020 ve sonrasında paylaşılan gönderilere karşı kamunun daha fazla etkileşim gösterdiği görülmektedir. Diğer yandan kullanıcıların aşırı duyarlı davrandıkları gönderiler üzerine bir değerlendirme yukarıda yer alan bölümde verilmiştir.

\section{Yorum sayısı}

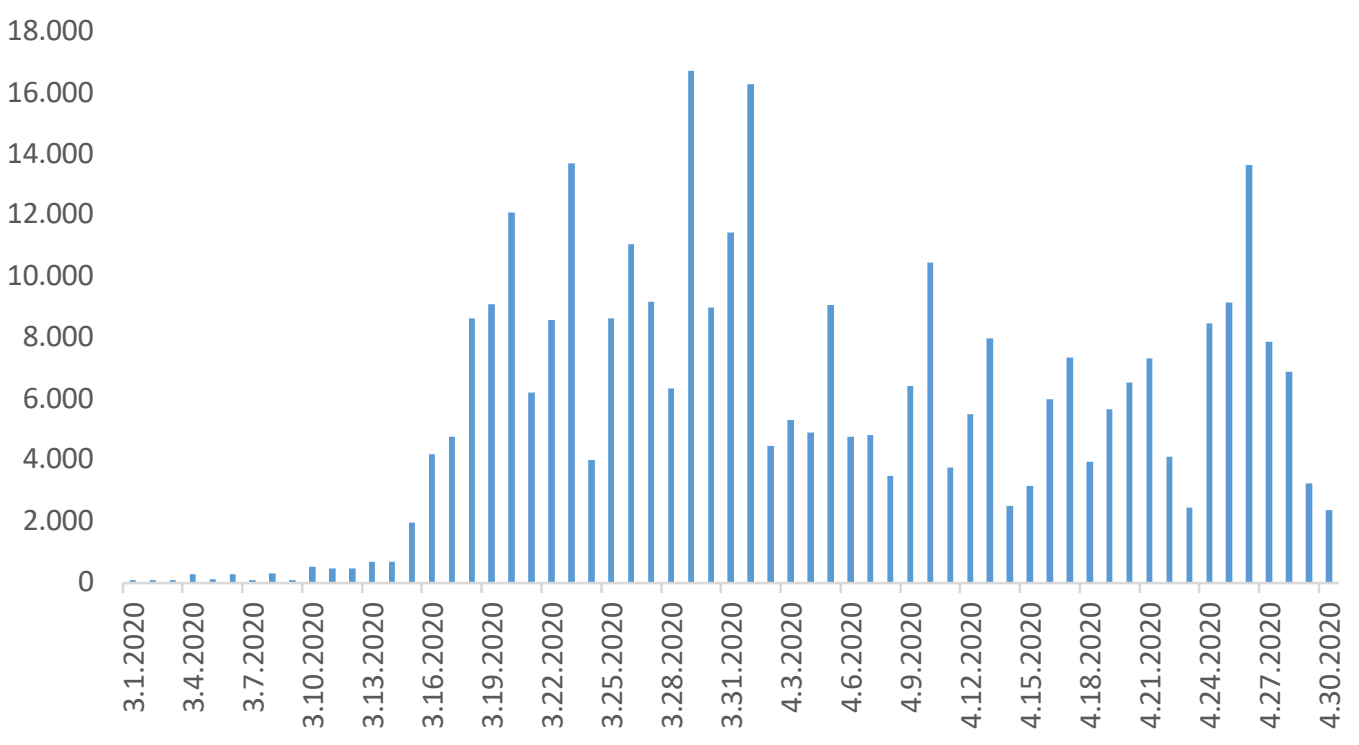

Grafik 4: Yorum Rakamlarının Gün Bazlı Değerlendirilmesi

Bu noktadan hareketle kamunun gönderi içeriklerini dikkate alarak yorum yaptıkları incelemeye alınan tarihlerdeki gönderilerde ortaya çıkmaktadır. Etkileşim kullanıcıların gönderinin kullanıcılarda etki yarattığı bu nedenle de yorum yaptıkları sonucunu ifade etmektedir noktasından hareketle içerikleri değerlendirdikleri ifade edilmelidir. Yorum bu noktada kamu için fikir ifade etme alanı olarak kuruma da kamuya ilişkin veri sağlama noktasında bir alan oluşturmaktadır. 


\section{SONUÇ}

Değişen ve yenilenen dünya farklı iletişim olanakları ile yeni medya uygulama alanlarıyla yeniden yapılandığı bir sürecin içindedir. Özellikle ekonomik ve siyasi etkenlerin gücüyle kamunun/hedef kitlenin/tüketicinin zihninde olumlu imajlar oluşturabilmek için stratejik planlar ile profesyonelce çalışılan bu dönemde tüm imkânlarının kullanıldığı görülmektedir. Rekabet ortamının küresel olarak koşullarını ağırlaştırmasıyla sadece ekonomik kaygıları olan kuruluşlar değil resmi kurum ve kuruluşlar da halkla ilişkilerin stratejik modellerinden faydalanmak yolunu seçmektedir. Grunig ve Hunt'ın halkla ilişkilerin tarihsel gelişimini esas alarak ortaya koyduğu modellerden ikinci basamak model olarak Kamuyu Bilgilendirme Modeli doğru ve gerçek bilgi akışının kuruluştan kamuya ulaştırılmasını destekleyen ve gerçekleştiren bir model olarak günümüzde de kullanılmaktadır. Bu modelin temel amacı manipülatif kaygılardan uzak biçimde kuruluşa ilişkin her türlü bilginin basın/medya aracılığıyla kamuya ulaşmasının sağlanmasıdır. Bugün gelinen yeni iletişim olanaklarının çerçevesinde sosyal medya uygulamaları ticari kuruluşlar kadar devlet kurumları tarafında da kullanılmakta bu noktada kamuya ulaşmak için bir araç olarak değerlendirilmektedir. Bu nedenle Türkiye'de de resmi kuruluşlar ve resmi makam sahipleri tarafından değerlendirilen sosyal medya uygulamaları kamuyu bilgilendirme modeli çerçevesinde değerlendirilerek diğer kuruluşlara bir bakış geliştirmek amacıyla ortaya konmuştur. Bu noktada bir sosyal medya uygulaması olan Instagram'da Dr. Fahrettin Koca'nın resmi hesabı incelenmiştir. Çalışma özellikle Covid 19 süreci içinde birinci dönem olarak ifade edilen dönemde 01 Mart 2020 ve 30 Nisan 2020 tarihleri arasında gerçekleştirilmiştir. Bu noktadan hareketle Instagram'ın ne şekilde kullanıldığı belirlenmiştir. Bununla birlikte kamunun bu gönderilere ne ölçüde etkileşim gösterdiği de incelenerek veriler ortaya konmaya çalışılmıştır.

Çalışmadan elde edilen bulgulara göre kamuyu bilgilendirme aracı olarak Instagram resmi bilgilendirme hedefi ile kullanılmaktadır. Yapılan bilgilendirmeler açık ve net bir şekilde gönderiler ile diğer kitle iletişim araçlarında paylaşıldığı biçimde gönderi niteliğine getirilerek paylaşılmaktadır. Kitle iletişim araçlarında yayınlanmak üzere değerlendirilen kamu spotları sosyal medya uygulamasında da aynı şekliyle paylaşılmaktadır. Bilgi çarpıtma (dezenformasyon) durumuna karşı bir bilgiyi düzeltme niteliği değerlendirilerek sosyal medya uygulaması kullanılmaktadır. Kullanıcılar/takipçiler/kamuoyu gönderilerin içerik niteliğine göre beğeni ve yorum yaparak etkileşim göstermektedir. Kullanıcılar özel gün/anma/teşekkür kategorisinde paylaşılan gönderilere sıklıkla etkileşim göstererek beğeni rakamlarını yukarı taşımaktadır. Diğer bir deyiş ile kamuoyu özel gün/anma ve teşekkür mesajlarına karşı duyarlıdır. Kullanıcılar kamuyu bilgilendirme niteliği ile paylaşılan gönderilere yorum kategorisinde daha fazla etkileşim göstermek ve gönderilerin altına fikirlerini ve yorumlarını yazmaktadır. Bu da kullanıcıların kamuyu bilgilendirme gönderilerine yorum bırakma noktasında daha duyarlı olduklarını ortaya koymaktadır. Kayda alınan tarihleri temel alan yorum ve beğeni rakamları takvim olarak incelendiğinde yükselen rakamlar kamuoyunun süreç ilerledikçe bilgilendirmeleri değerlendirerek hesabı takip ettiği sonucunu ortaya koymaktadır. Bu da kaynağa güvenirliğin artığının da arttığını gösteren bir gösterge olarak değerlendirilebilir. Bu çalışmada aynı zamanda yenilenen Türkiye' nin yeni medya uygulamaları çerçevesinde resmi kuruluşlar tarafından sıklıkla tercih edildiği ve kamunun da bu kanal ile bilgi almayı tercih ettiği ortaya konmaktadır. Türkiye Cumhuriyeti Sağlık Bakanı Dr. Fahrettin Koca kısa sürede 8,6 milyon takipçi rakamına ulaşmış ve önemli sayılacak bir kitleye bilgi aktarımını Instagram kanalıyla gerçekleştirmiştir. Bu değerlendirme çok daha geniş bir çalışmanın kapsamında Sağlık Bakanlığı'nın bu süreçte özellikle basın ilişkilerini nasıl düzenlediği ve bilgilendirme çalışmalarını diğer kanallarda da nasıl gerçekleştirildiğinin analizi noktasında da yapılabilir. Bu bağlamda belirtilmelidir ki süreç dâhilinde hastalığın ilk dönemi olarak ifade edilen bu dönemde 
Türkiye uyguladığı politikalar ile dünyanın ilgisini kazanmış ve güçlü bir ülke imajı elde etmiştir. Diğer bir deyiş ile küresel salgının ilk dönemini Türkiye kriz yönetimi bağlamında da başarıyla geçirmiştir.

Sonuç olarak yapılan bu çalışma Covid 19 salgını çerçevesinde belli bir dönemi esas alarak Instagram üzerinden gerçekleştirilmiştir. Bu çalışma sonuçlarına göre kamuoyunu bilgilendirme aracı olarak kurumların Instagram'ı kullanmasının gereklilik olduğu söylenebilir. Bu uygulama kullanılırken de diğer yapılan bilgilendirmeler ile eş zamanlı olarak uygulamaları değerlendirmek gerekliliğidir. Bir diğer nokta ise kamunun özellikle etkileşim gösterdiği içeriklerin değerlendirilmesi ve kamunun bu bağlamda hassasiyet gösterdiği noktaların tespiti olarak da iki yönlü simetrik modele doğru mükemmel halkla ilişkiler modeline doğru yaklaşmaya çalışmaktır.

\section{KAYNAKLAR}

Bergström, T. and Backman, L. (2013). Marketing and Pr in Social Media, Jmk, Department of Journalism, Media and Communication Bachelor Thesis, Stockholm University.

Çömlekçi, M. F. (2019). Sosyal Medya Dezenformasyon ve Haber Doğrulama Platformlarının Pratikleri, Gümüşhane Üniversitesi İletişim Fakültesi Elektronik Dergisi, Cilt/Volume 7, Uluslararası Türk Dünyası Basın Sempozyumu Özel Sayısı.

Erdoğan, İ. (2006). Teori ve Pratikte Halkla İlişkiler, Pozitif Yayıncılık, Ankara.

Ertekin, Y, (2000). Halkla İlişkiler. Ankara: Yargı Yayınevi. No: 28. Dördüncü Baskı.

Göçoğlu, V. (2019). Türkiye'de Merkezi Yönetimin Sosyal Medya Kullanımı: Bakanlıkların Twitter Hesapları Üzerine Bir Analiz, Uluslararası Yönetim Akademisi Dergisi, 2(2): 422-444.

Grunig, E.J. and Hunt, T. (1984). Managing Public Relations, Wadsworth/Thompson Learning, Newyork.

Grunig, James E., (1990). Theory and Practice of Interactive Media Relations, Public Relations Quarterly, 35 (3): 18-23.

Harrison, S., (2004). Public Relations: An Interaction, Cornwall: Thomson Learning.

http://www.sp.gov.tr/tr/stratejik-plan/s/1563/Genclik+ve+Spor+Bakanligi+2018-2022 Erişim Tarihi 08.05.2020

https://covid19bilgi.saglik.gov.tr/tr/ Erişim Tarihi 27.04.2020

https://ohiostate.pressbooks.pub/stratcommwriting/chapter/four-models-of-public-relations/ Erişim tarihi 13.05.2020

https://www.aa.com.tr/tr/turkiye/dso-genel-direktoru-ghebreyesus-saglik-bakani-kocayi-sosyalmedyada-takibe-aldi/1825274 Erişim Tarihi 10.05.2020

https://www.icisleri.gov.tr/ Erişim tarihi 01.05.2020

https://www.instagram.com/drfahrettinkoca/ Erişim Tarihi 01.03.2020

https://www.rtuk.gov.tr/spot-filmler/3717/3985/kamu-spotlari-yonergesi.html Erişim Tarihi 03.05.2020

Kazaz, M. ve Tümen, E. (2013). Tanıtım Amaçlı Sosyal Medya Kullanımı: Gençlik ve Spor Bakanlığı Örneği, 1. Kop Bölgesel Sempozyum Kitabı, Konya: 88-97. 
Khang H, Ki E-J. and Ye L. (2012) Social Media Research in Advertising, Communication, Marketing, And Public Relations, 1997-2010, Journalism \& Mass Communication Quarterly, 89(2): 279-298.

Koçak, A. ve Arun, Ö. (2006). İçerik Analizi Çalışmalarında Örneklem Sorunu. Selçuk İletişim Dergisi, 4(3): 21-28.

Okay A. ve Okay A. (2002) Halkla İlişkiler Kavram, Strateji ve Uygulamaları, Der Yayınları, İstanbul.

Özçelik H. ve Konuk, N. (2020). Yerel Yönetimlerde Sosyal Medya Kullanımı: İETT Örneği 1. Uluslararası Yeni Dünyada iletişim Kongresi Kongre Özet Kitabı, İksad Yayınevi, Adana.

Özgen, E. (2012). Sosyal Medya ve Halkla İlişkilerde Değgişen Medya Anlayışı, Tolga Kara-Ebru Özgen (Eds), Sosyal Medya Akademi, İstanbul: Beta Basım Yayım.

Peltekoğlu, F. B., (2009). Halkla İlişkiler Nedir?, İstanbul: Beta Yayınları.

Tarhan, A. (2012). Büyükşehir Belediyelerinin Sosyal Medya Uygulamalarına Halkla İlişkiler Modellerinden Bakmak, İletişim Kuram ve Araştırma Dergisi, Naci Bostancı Özel Sayısı, Sayı: 35: 79-101.

Tavşancıl, E. ve Aslan A. (2001). İçerik Analizi ve Uygulama Örnekleri. İstanbul: Epilson Yayınevi

Yüksel, F. (2005). Bilgi Teknolojileri ve Yerel Yönetimler, Selçuk Üniversitesi Sosyal ve Ekonomik Araştırmalar Dergisi, 10, 247-259.

www.brandingturkiye.com Erişim Tarihi: 04.05.2020

www.instagram-press.com Erişim Tarihi: 04.05.2020 